\title{
THE PUNISHMENT OF TARPEIA AND ITS POSSIBLE ICONOGRAPHIC INSPIRATION*
}

\author{
LENKA VACINOVÁ
}

\begin{abstract}
The motif of the Punishment of Tarpeia is surprisingly rare in Roman visual arts. However, the surviving examples show iconographical unity and imply their common primary visual source of inspiration. The article is exploring the possible models considering the less obvious iconographical similarities and resemblances in terms of content found in the Greek art. The cases of the infamous intriguer Dirce and traitor Dolon are discussed, as well as the remarkable resemblances found on some images of the Death of Caeneus. While the latter indicates the inspiration based on free associations and the similar circumstances of death of the both protagonists, Dolon and Dirce seem to influence the creator of the iconographic scheme of the Punishment of Tarpeia in a more straight way.
\end{abstract}

Keywords: iconography; Tarpeia; betrayal; punishment; exposure; nudity

Roman art is abundant in the iconographic paradigms borrowed from Greek visual arts, as well as in scenes with no such close and apparent parallels. The story of Tarpeia's treachery and her punishment seems to belong to the latter group.

The tragic tale of a girl who, enchanted by the golden bracelets of the enemy, betrays Rome to the Sabine king Titus Tatius under the promise of "what the Sabines wear on their left hands" and who instead meets her fate under a pile of their shields (which the Sabines unfortunately also carry on their left arms), is dealt with both by Greek and Latin authors in a quite different versions. ${ }^{1}$ On the contrary, the scarcely preserved depictions of Tarpeia seem to share almost the same iconographic scheme. Only three examples of

* This work was financially supported by Ministry of Culture of the Czech Republic (DKRVO 2017/25, National Museum, 00023272).

1 Besides the notorious basic story recorded by Liv. I, 11, 5-9 or Prop. IV, 4, Plut. Rom. 17, 5-6 cites two completely different versions: Tarpeia being a daughter of the Sabine king, i.e. no traitor at all; or she betrayed Rome to the Gauls, not the Sabines. Dion. Hal. Ant. Rom. II, 38, 32-40, 3 preserves the version of historian L. Calpurnius Piso Frugi, who is too eager to make Tarpeia a Roman patriot trying to rescue her city by tricking the Sabines and by depriving them of the protection of their shields. For a more detailed survey of ancient authors concerning Tarpeia see e. g. Cairns (2011: 176-184) or most recently and extensively Welch (2015). 
this dramatic event have survived: the relief slab of the frieze from Basilica Aemilia ${ }^{2}$ and two coin types - the Republican denarii minted by L. Titurius Sabinus in 89 BC $^{3}$ and the Augustan denarii issued by P. Petronius Turpilianus 70 years later. ${ }^{4}$

In all three cases a frontal figure of a kneeling young woman covered with shields up to her hips forms the focal point and main vertical axis of the scene. The most complicated composition is found on the relief from Basilica Aemilia (Fig. 1), where the Punishment of Tarpeia forms part of a much longer and more complex narrative cycle probably centred on the character of Romulus and the events that gave rise to great Roman festivals. ${ }^{5}$ The scene of the Punishment itself consists of five figures; its focal point is, however, the girl with one breast bared and with swelling veil over her head, stretching her hands towards two soldiers standing on both sides of her. On the left, we can see an almost frontal man wearing a lorica and galea and preparing to throw the oval shield on his victim, on the right a bare-headed soldier in exomis, standing with his back to the viewer, is ready to throw another shield (scutum). Two bearded and helmeted men in armour standing by without any action on the far sides are most probably Titus Tatius and Mars Ultor rather than Romulus himself. 6

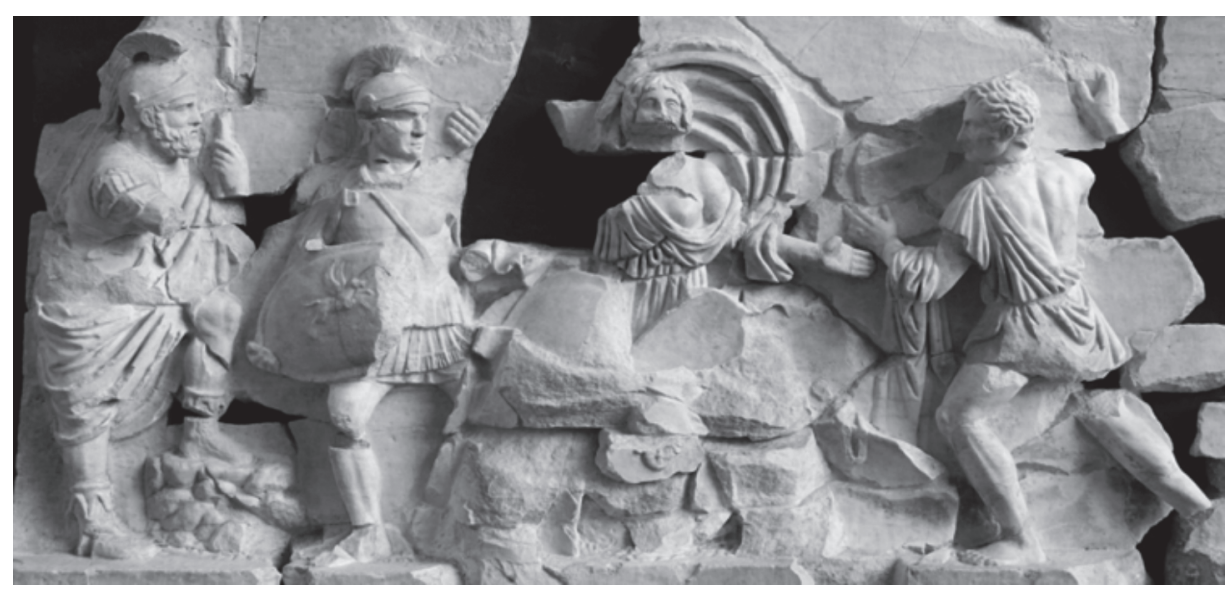

Fig. 1. The Punishment of Tarpeia. Basilica Aemilia frieze. Museo Nazionale Romano. The figure of the soldier in the right corner of the scene is missing on this photograph.

2 Slab no. 9, first published by Bartolli (1950: 289-294). The Punishment of Tarpeia is preceded by the Rape of the Sabine women and followed by the scene most convincingly interpreted as the Matronalia - cf. Albertson (1990: 807) or the preparations of Hersilia's marriage with Romulus - cf. Evans (1992: 131).

3 RRC 344/2. All the three types of Titurius' denarii bear the bearded head of the Sabine king Titus Tatius on the obverse. On the reverse of the first type the Rape of the Sabin women (RRC 344/1) is depicted, on the third type Victory in biga (RRC 344/3). The complex iconography and ideological programme of Titurius Sabinus' coinage is particularly interesting, but it is beyond the scope of this article; for more detailed insight into this subject see e.g. Evans (1992: 120-127) or Welch (2015: 76-102).

4 BMC I Augustus 29-31; RIC I Augustus 299.

5 Albertson (1990: 808).

6 Furuhagen (1961: 142-144); Evans (1992: 121-122). 
In the much more limited space of the denarii minted by L. Titurius Sabinus (Fig. 2), the same scene consists of three figures only: two identical mirror-arranged figures of the Sabine soldiers with raised shields attack Tarpeia kneeling in the centre amid the heap of shields. Her hair is ragged, but her breasts remain draped, and her hands are stretched strictly symmetrical towards the executioners.
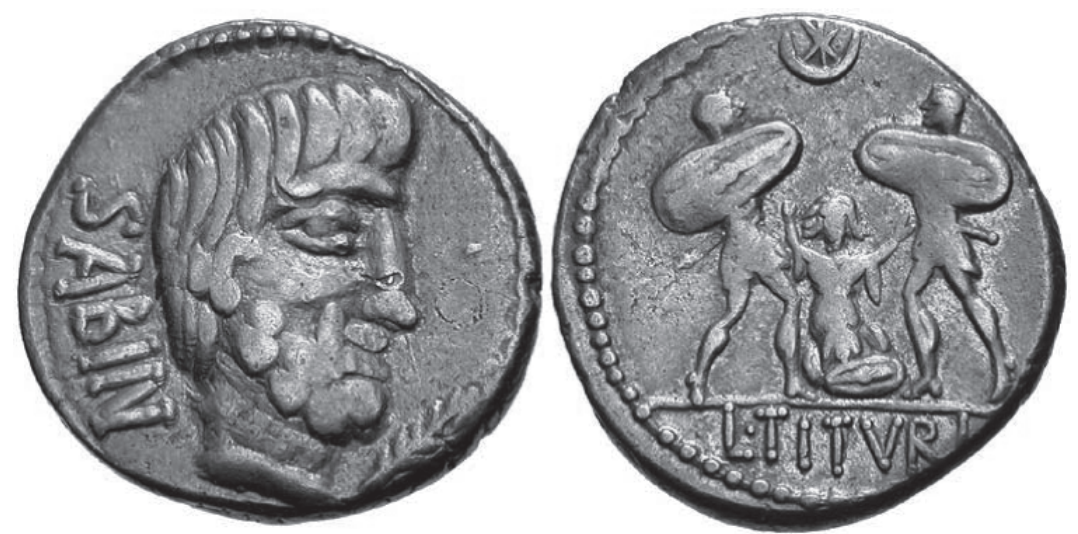

Fig. 2. The Punishment of Tarpeia. AR denarius, L. Titurius Sabinus, 89 BC. RRC 344/2.

Finally, on the denarii of Petronius Turpilianus (Fig. 3) the whole scene is reduced only to the character of Tarpeia herself, standing or kneeling in the centre of the coin image amid the high pile of the shields with both hands up symmetrically, as if surrendering.
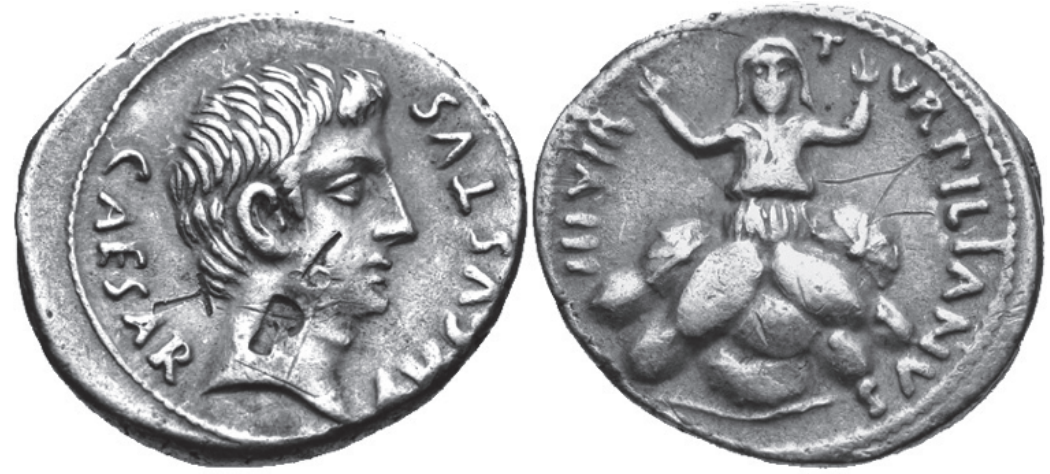

Fig. 3. The Punishtment of Tarpeia. AR denarius, Augustus, issued by P. Petronius Turpilianus, 19 BC. RIC I Augustus 299.

In spite of the varying number of the figures and minor details, all the three discussed images share the main feature - figure of Tarpeia - in a very specific position, clearly identifiable by the presence of heap of shields. It seems obvious they share the same iconographic model. ${ }^{7}$ The most probable date of the Basilica Aemilia reliefs seems to be the

7 Küter (2014: 92); Evans (1992: 122). 
period $55-34 \mathrm{BC},{ }^{8}$ the oldest preserved depiction of the Punishment is thus found on the denarii of L. Titurius Sabinus. The coin, of course, could hardly have been a model for the frieze itself. An earlier common source of inspiration is thus assumed. It could well have been the image of Tarpeia in the temple of Jupiter Stator mentioned by Festus. ${ }^{9}$ Unfortunately we have no more detailed information about this monument (not even knowing if he is writing about a wall painting or sculpture, although the second possibility seems to be more meaningful, nor even Festus himself seems to be sure about its identification). ${ }^{10}$ Of course, we may think of another image, relief or fresco portraying the Punishment of Tarpeia, as Alföldi already suggested. ${ }^{11}$ Anyway, this hypothesis just postpones a more important and crucial question - what iconographic paradigm was originally used for creating Tarpeia's image in Roman art? What was the first visual source of the inspiration?

As a purely Roman legend the story of Tarpeia had no tradition in the Greek or Etruscan visual arts, i.e. its iconographic scheme had to be artificially composed and established relatively late, undoubtedly on the basis of models taken from elsewhere. Greek visual arts were commonly used as a rich source of inspiration in Roman times, as is attested by the ancient authors explicitly in the case of creating triumphal paintings - the Greek artists were even invited to take part in it. ${ }^{12}$ As for the mythological or supposedly historical legendary scenes, the Rape of the Sabine women on other type of Titurian denarii and on Basilica Aemilia frieze is a good example of re-using the original Greek iconographic scheme both in the miniature arts and in sculpture. ${ }^{13}$ On the contrary, it is generally assumed that the scene of the Punishment of Tarpeia is lacking such an obvious visual parallel. ${ }^{14}$

Instead of searching for visual and linguistic similarities between the image of Tarpeia and tropaeum which have proved unsatisfactory, ${ }^{15} \mathrm{I}$ believe we should start also in this case with Greek art and consider not only its visual, but also its narrative parallels of the scene as well.

How could the ancient (Greek or Roman) artist facing the challenge of portraying Tarpeia for the first time have proceeded? Greek mythology knows a good deal of tragic heroines who made a fatally bad choice as Tarpeia did and received a similar punishment. ${ }^{16}$ Scylla, the daughter of Nisus of Megara, is probably the most famous one. She falls in love with hostile king Minos and brings him her father's magic lock of hair, but

8 For a brief survey on various dating of the frieze, see e. g. Albertson (1990: 801-802); Evans (1992: 129-130).

9 Fest. 496 (Lindsay): Tarpeiae esse effigiem ita appellari putant quidam in aede Iovis Mettellina.

10 Richardson (1992: 221).

11 "The prototypes of the scenes ... must be sought in wall-paintings and reliefs decorating the atria of the nobles" (Alföldi 1956: 80).

12 Holliday (1997: 136 and 141-142).

13 For its iconographic models and parallels see e.g. Böhm (1997: 86-89).

14 "Aus einem griechischen Bildrepertoire schöpfte man jedenfalls nicht" (Böhm 1997: 92).

15 Cf. Gansiniec (1949). However, the idea connecting the origin of the image of Tarpeia with tropaeum comes from Reinach (1908: 43-74). The arguments are substantially aetiologic. For extremely brief, but convincing enough polemics see Weinstock (1955: 239-240). Especially cogent is his remark that "Tarpeia cannot be separated from the gens Tarpeia, mons Tarpeius, saxum Tarpeium or from other legendary figures", emphasizing her close connections with the history and topography of Rome. Anyway, recently Küter (2014: 92-93), considering the denarii minted by Turpilianus, does not reject the tropaeum hypothesis entirely.

16 There is no doubt that the stories about these perfidious girls and women have inspired some details and embellishments in the story of Tarpeia itself, especially the poem of Propertius, who romanticizes the reasons of Tarpeia's betrayal with the additional motive of her passion for the Sabine king. 
instead of winning Minos' love, he puts her to death. ${ }^{17}$ Comaetho, daughter of Pterelaus, replicates almost the same pattern with Amphitryon, ${ }^{18}$ as does Pisidice of Methymna, stoned to death for betraying her city to Achilles. ${ }^{19}$

Nevertheless, these treacherous colleagues of Tarpeia were, as far as we know, portrayed (if ever) in a quite different moment of their tragic story - during the very act of the betrayal: Scylla of Megara is always depicted delivering the lock of her father's hair to Minos on the preserved Roman wall-paintings. ${ }^{20}$

Of course, this model was hardly suitable for Tarpeia's tale which is lacking such a clearly identifiable moment. Moreover, there were good reasons for focusing on the act of her death itself - first, it is the most dramatic part of the story, involving also a cathartic moment - the evil is punished; secondly, it appears in all variants of the myth; thirdly, it is so characteristic, unique and irreplaceable, really iconic in that sense that we are able to identify what is going on at the first glance (knowing the story, of course); and last but not least - its ideological function cannot be underrated - it is an exemplar providing a clear moral message and warning.

Having chosen this subject, we would probably look for the images of the heroines who died in a similar way as Tarpeia did at least. Pseudo-Plutarch in his parallel Greco-Roman stories names together with the Roman traitor the treacherous Demonice of Ephesus. ${ }^{21}$ The only differences are that Demonice falls in love with Brennus, betrays her city to the Gauls and is killed actually under the pile of promised golden bracelets. Polycrite of Naxus was also reported to die under the weight and quantity of the jewellery thrown on her by the grateful fellow-citizens she saved from the besiegers of her city by a stratagem. ${ }^{22}$ Her patriotic motivations remind that of Tarpeia in Calpurnius Piso's version of story, but even if Demonice or Polycrite were found an appropriate visual model for the image of the death of Tarpeia, again, it seems there was no applicable iconographic inspiration, as in the case of the other above-mentioned Greek mythical traitors.

What next then? It was necessary to look around for another model, resembling the story of Tarpeia in a less direct way and on the basis of less complex similarities. I would like to propose and examine three examples showing such partial, but significant parallels, both visual and in terms of content.

\section{The Punishment of Dirce}

Although Dirce is not technically considered as a traitor, her acts are launched against her kin, i.e. they are ranked among the highest crimes. Worse than death of Antiope itself would have been probably the fact that her intrigue would have made Amphion and Zethus murderers of their own mother. As the fame of the notorious Farnese Bull and

17 Aesch. Lib. 612-620; Paus. I, 19, 4; Apollod. III, 15, 8.

18 Apollod. II, 4, 8.

19 Parthen. Erot. pathem. 21.

20 LIMC Skylla II.

21 Plut. Paral. min. 15.

22 Parthen. Erot. pathem. 9. 
series of Roman frescoes and mosaics attest, the story and the Dirce's cruel punishment especially were fairly familiar to the Hellenistic as well as to Etruscan and Roman publics.

However, I would like to call attention to not-so-famous pieces of art displaying this motif - the Etruscan sarcophagi ${ }^{23}$ (Fig. 4) depicting the death of Dirce in similar way as the Basilica Aemilia frieze represents the execution of Tarpeia.

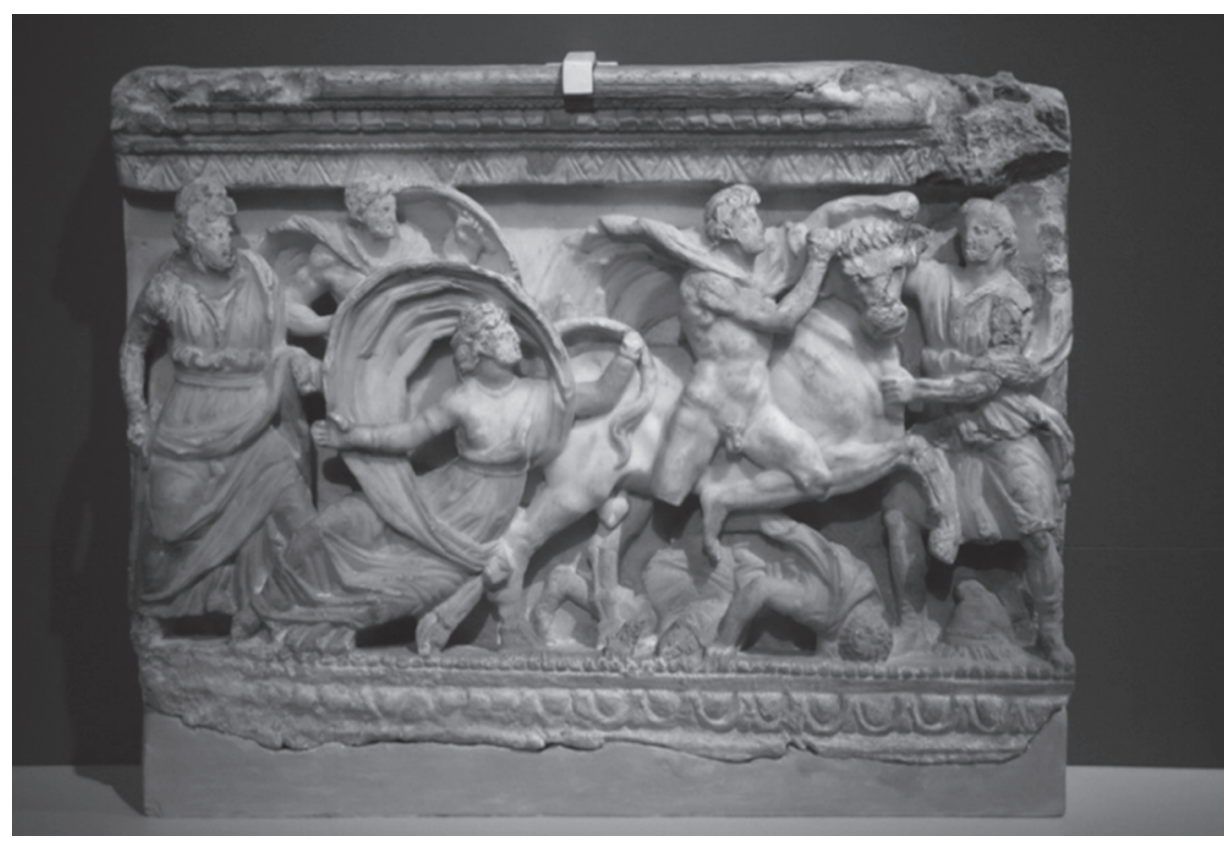

Fig. 4. Etruscan alabaster cinerary chest with the relief showing the Punishment of Dirce, from Volterra. 120-110 BC. Staatliche Museums Berlin, no. 1278.

Although Dirce is not placed in the centre of the scene, the position of her falling body and of kneeling Tarpeia is strikingly similar; notable resemblances show especially the swelling veil over the woman's head, her bare breast and the gesture of the both hands.

On the gem in Museo Nazionale in Aquileia ${ }^{24}$ the composition is probably inspired by the Farnese Bull, it is however strictly symmetrical, including almost identically moving figures of the brothers. Kneeling Dirce with exposed breasts is placed in the centre of the image.

As for a bared breast, this feature is in specific situations common characteristic for woman experiencing some kind of a violent attack. ${ }^{25}$ However, in terms of this category it is necessary to distinguish the sexually motivated scenes, where the bared bosom conforms to the narrative (especially the scenes of abduction), from depictions where the erotic effect of the exposed body is totally unwelcome.

23 Berlin, Statl. Mus. 1278 (LIMC Dirke, no. 8); Museo Guarnacci 505 (LIMC Dirke, no. 9).

24 Richter (1971: 71, no. 333).

25 "Female breasts are exposed by garments violently ripped or loosened on account of violent interaction with others" (Cohen 1997: 72). 
This category of scenes with non-intended or seeming sexual appeal is surprisingly extensive. Besides the Wounded Amazons of Ephesus and their less-famous fellow-warriors, we find not only Dirce or Clytemnestra being punished by Orestes, ${ }^{26}$ but also Cassandra being attacked by Clytemnestra, ${ }^{27}$ Cohen names also some daughters of Niobe, Procris, Canace, Lycurgus' wife and Callisto, ${ }^{28}$ I would remind Iphigenia being rescued by Artemis right during the act of her sacrifice, ${ }^{29}$ and perhaps also Andromeda in the similar situation. In terms of her story she was primarily supposed to be offered to a monster, not to marry or seduce Perseus - her bared breast on some paintings, especially on the frescoes from Pompeii, could be reminder of this original intention. ${ }^{30}$

Furthermore, I believe that in the framework of this category of non-intended erotic appeal we can actually define two separate but very closely related subgroups - the first one encompasses negative characters, transgressors, whose infamous deeds violate the social rules and endanger the family or the whole community (Dirce, Clytemnestra). These women are exposed to execution which comes from the hands of the mortals.

To the second related subgroup belong indirect forms of the punishments - the innocent victims suffering for their parents' sins, usually acts of impiety, hubris (Niobe, Cassiopeia, Agamemnon). In these cases, the transgressor pays for his / her guilt not with his / her own life, but by the loss of the offspring (that the death of the progeny is not necessarily accomplished has no relevance here).

As stated above, in all the named cases the erotic effect is hardly designed. What was the reason then for exposing the bodies of those girls and women? In Western culture, it seems quite hard to perceive almost omnipresent female nudity in visual media in other way than as sexual objects. Anyway, I assume that in the above discussed cases, although the aesthetic and erotic effect cannot be totally separated, we are not primarily confronted with nudity itself, but with the dress, its state and its eventual presence or absence. Nakedness is just a secondary natural effect here.

Of course, the basic and completely natural function of the dress in everyday life was to protect the body from external threats (weather as well as the eyes of the strangers). I believe this function of women's dress is metaphorically amplified and symbolically extended in the visual arts and it is closely associated with the personal safety of the wearer.

The inappropriate state of clothes causing exposure of the body indicates fatal endangering of a person and even possible loss of her life. Similarly, the lifted veil or overfall swelling over (mortal) woman's head is in the dramatic scenes often used as an independent means of protection (however hardly effective in real world) for females desperately looking for a shelter or at least terrified by witnessing a fatal event. The statues of

${ }^{26}$ Except the scenes where she is completely naked - probably in reference to her adultery with Aegisthus. Her exposure of a breast could of course remind of Aeschylus' tragedy, where Clytemnestra tries to placate her son by exposing her breasts that gave him suck, as probably on the red figure neck amphora from Paestum, ca. 340 BC, in Getty Museum. In the case of Dirce, however, the reason for self-exposure is missing.

27 In the tondo of red figure kylix attributed to Marlay Painter, ca. 430 BC, Ferrara, Museo Nazionale di Spina 2482 (Beazley 1963: 1280, no. 64).

28 Cohen (1997: 77).

${ }^{29}$ Hellenistic group of Artemis with Iphigenia and a deer in Ny Carlsberg Glyptotek in Copenhagen.

30 Especially the wall paintings from Pompeii, the most famous one from Casa dei Dioscuri (LIMC Andromeda, nos. 67-71), but also some red figure craters from Lucania and Sicily (LIMC Andromeda, nos. 22-23). 
Niobids from the group found in the Gardens of Sallust seem to be a good example: The Fleeing Niobid ${ }^{31}$ is using the lifted overfall of her peplos as to take it as a shelter, while her sister (Stumbling Niobid) ${ }^{32}$ already hit with an arrow to her back is portrayed kneeling in agony, almost fully disrobed.

Even the scenes of abduction in which the nudity retains its eroticizing function, the poor state or absence of clothing also echoes the loss of protection from relatives or friends, vulnerability of the victim as well as her exposure to violent behaviour.

Although the swelling veil becomes purely decorative aesthetic feature in later Roman art (not mentioning the scenes depicting goddesses, where it has totally different meaning), the Basilica Aemilia frieze does not seem to be that case yet. The threat expressed by Tarpeia's bared breast and her desperate search for shelter fit totally with her fatal situation as well as with the lasting tradition of the visual expression of imminent danger.

Considering that, I have to strongly disagree with Mrs. Welch, who concludes that Tarpeia with bared breast has anything to do with Amazons. ${ }^{33}$ They belong to the group of women exposed to violence which is indicated by the common means of expression. But the only other link between them could be their supposed ritual virginity. ${ }^{34}$ In any case, Tarpeia has definitely more in common with ungodly women like Dirce and Clytemnestra, who are not anonymous representatives of a collective body, but particular individuals with their own names and tragic stories, facing the consequences of their unrighteous act against their relatives (not an enemy!) and expecting a well-deserved death penalty. On all accounts, they are no fighters and do not play fair at all - on the contrary - they are spurious and cheating malicious characters.

Even the gesture of hands of Tarpeia on the Basilica Aemilia frieze almost mirrors the movement of Dirce on the above-mentioned Etruscan sarcophagi. However fragmentary the right part of Tarpeia's body is, it is possible to restore the original position of the right arm (her left arm on 4 o'clock, the right on 10 o'clock) thanks to the surviving palm. Panic or resignation - all these emotions fit well with the situation of both executed women.

Another possible meaning of this motion - a gesture of a begging suppliant - brings us to the second candidate for a model for Tarpeia's image.

\section{Execution of Dolon}

Although Dolon is a male, the parallels between him and Tarpeia are obvious - their guilt and its consequences are almost of the same rank. The Trojan scout captured by Ullyxes and Diomedes during his night adventure reveals to the enemy the strategic information about his maternal city and its allies without hesitation. His expansiveness leads at least to the death of the Trojan ally king Rhesus of Thrace, i.e. Troy is deprived of one of her mighty defenders.

Dolon as well as Tarpeia is thus guilty of parricide. And the almost immediate punishment of death comes (sic!) in both cases not from the hands of their betrayed kin, but

31 Ny Carlsberg Glyptotek Coppenhagen no. 398.

32 Museo delle Terme no. 72274.

33 Welch (2015: 131-132).

34 Tarpeia is first explicitly said to be a Vestal virgin by Varro Ling. V, 41. 
from the enemy who took advantage of their weakness. Furthermore - Dolon's motivation (although for his quest, not the betrayal itself) is - as in Tarpeia's case - greed and his desire for the divine horses of Achilles promised to him by Hector.

It is therefore no surprise that the representations of Tarpeia and Dolon in visual arts show substantial similarities. The closest parallel which could have stand for a model for the Punishment of Tarpeia on the Titurian denarii we can find also in the miniature art. Three gems dated to the $3^{\text {rd }}-2^{\text {nd }}$ centuries $B C^{35}$ (Fig. 5) show Dolon just like Tarpeia in the centre of the image, kneeling amid two standing punishers - the position known from many other representations of the execution of defeated enemy. The motion of Dolon trying to touch with the right hand Ullyxes' chin and with the left hand Ullyxes' knuckle is unambiguously the specific pose of a suppliant begging for mercy. This gesture, literally illustrating Homer's description, ${ }^{36}$ is thus lacking the symmetry of the figure of Tarpeia on the Titurian denarii. The interpretation of her pose as that of suppliant thus remains only hypothetical. However, yet another paradigm for image of Tarpeia could have been used.

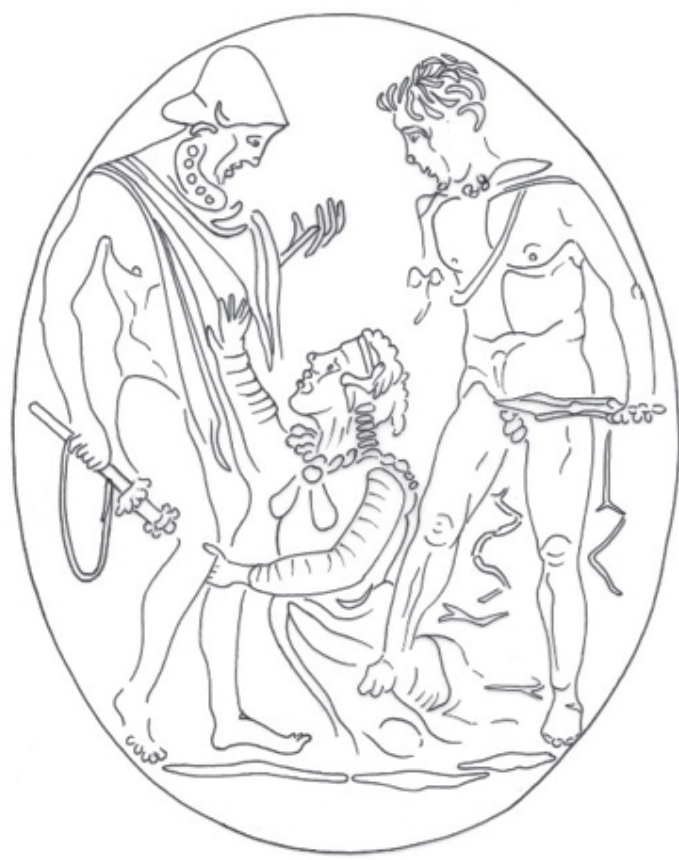

Fig. 5. The gem with the Death of Dolon. Museum of Fine Arts, Boston (MFA 27.740). Drawing: A. Waldhauserová.

35 The images on gems in British Museum (BM 1867, 0507.444; Richter 1971: 64, no. 298) and in the Museum of Fine Arts in Boston (MFA 27.740; Richter 1971: 65, no. 299) are almost the same. The second gem in British Museum (MB 1896, 1021.2; Smith, Murray 1888: 160, no. 1394) is of a poorer quality and damaged. The iconographic scheme itself is attested already on the red-figured Campanian bell crater from the $3^{\text {rd }}$ third of the $4^{\text {th }}$ century BC (cf. LIMC Dolon, no. 18).

36 Hom. Il. X, 315-455. 


\section{The Death of Caeneus}

The closest iconographic parallels to the Punishment of Tarpeia on Titurius' denarii are rather surprisingly some representations of Lapith Caeneus who is no negative or perfidious character at all. Anyway, the images of the violent deaths of both figures show remarkable similarities which can hardly be accidental. ${ }^{37}$ Both tragic heroes die under the pile of tools (in the case of Caeneus stones or logs) mound by the attackers above their bodies while still alive. In all cases these tools can be hardly considered as typical offensive weapons.

The axial symmetry of the scene with the victim kneeling in the centre between the two attackers is no innovation. But the mirror gesture of Tarpeia on the Titurius' denarii rising both hands and touching the Sabine soldiers recalls strikingly the motion of Caeneus thrusting the swords or spears with both his hands symmetrically into his opponents' bodies ${ }^{38}$ (Fig. 6).

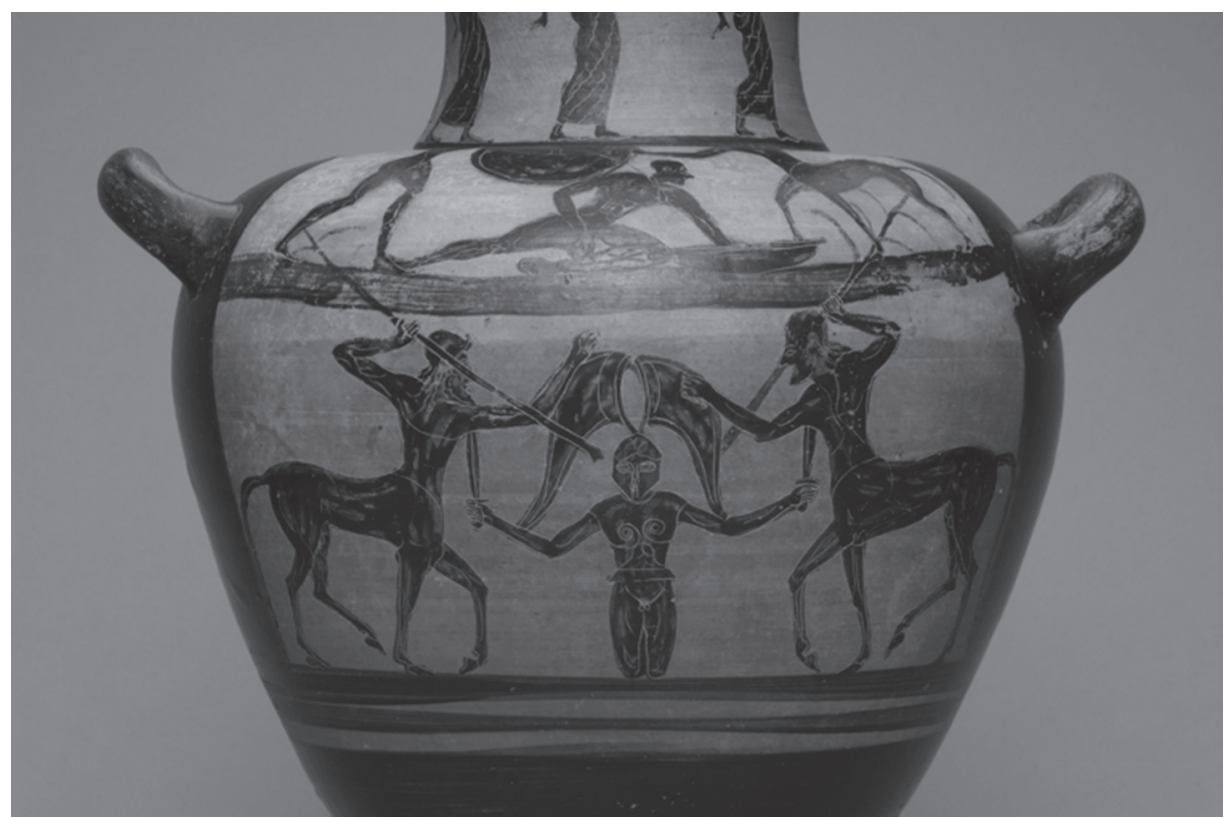

Fig. 6. The Death of Caeneus. Etruscan black figure stamnos. Kunsthistorisches Museum Wien no. 406 IV 1477.

No less remarkable is also the motive of the shields in spite of the fact that in the depiction of the Punishment of Tarpeia they are used as offensive lethal weapons (what a Sabine irony, indeed!) and in some scenes of the Caeneus' fight as defensive ones.

37 For complete iconography of Caeneus, see Laufer (1985).

38 E.g. Etruscan black figure stamnos in Kunsthistorisches Museum in Wien, no. 406 IV 1477, see Laufer (1985: Taf. 8, Abb. 22); relief lid of the sarcophagus from Limyra and architecture relief from Mylasa, see Laufer (1985: Taf. 18, Abb. 59 and 64). 
The Death of Caeneus is an old iconographic scheme known from the archaic period onward, usually as an organic part of the Centauromachy. It was also familiar in Italy, as the abundance of South Italian red-figure vases attest, ${ }^{39}$ and it was apparently well known to the Etruscans as well, ${ }^{40}$ but curiously enough in the Roman visual arts the story of this Lapith is almost completely missing. ${ }^{41}$ In any case, the old and almost abandoned iconographic scheme could have become an inspiration for a new one. Of course, this process had to be based purely on a mere association, resulting exclusively from the specific details of the way of death of Tarpeia and Caeneus; any other similarities in their stories are lacking.

\section{Conclusion}

There is similar guilt, the same penalty, the same horror, the same way of dying. From this point of view, we can hardly find any novelty either in the story or in the iconography of a punished transgressor. There is no doubt that the creator of the image of Tarpeia in the visual arts had a broad armoury of means of expression to choose from.

It seems that there was not just one model - probably because not even one of them showed complex similarity to the story of Tarpeia in all details. The resulting pictures, which differ slightly, could have combined different elements from different stories, chosen on the basis of more or less obvious resemblances or just free associations.

Tarpeia, her story as well as iconography of her bitter end, clearly belongs first of all with the punished offenders like Dirce and Clytemnestra. As for the possible male iconographic inspirations (however complicated the gender of Caeneus and all his story can be), they seem to confirm that gender is no extenuating circumstance in the case of betrayal. On the contrary, it could be the aggravating one - the women trespassers (transgressing more limits than men) are often exposed to a more violent behaviour.

The identification of the original source of inspiration for the image of Tarpeia's death, if right, can also help us to perceive the process of the translation of iconographic schemes from Greek art into the Roman world and the process of visualization of the new themes. Considering the Greek treacherous colleagues of Tarpeia - Dirce and Dolon as the main models, we can probably also state that in spite of the painstaking efforts of L. Calpurnius Piso Frugi, Tarpeia was never universally considered to be a positive figure. And last but not least, in the case of denarii it could also help us to understand better the intentions of the moneyer and the message encoded in his coin image.

39 LIMC Kaineus, nos. 50-53 and 63-64.

40 Attachment of Etruscan helmet from Orvieto, see Laufer (1985: Taf. 14, Abb. 44).

41 The only exception seems to be the arula from Rome, dated to the $3^{\text {rd }}$ or $2^{\text {nd }}$ century BC, in Museo Capitolino A 9143, Laufer (1985: 33-34). Here, anyway, the scheme is reduced - Caeneus is attacked by only one Centaur. 


\section{REFERENCES}

Albertson, F. C., 1990. 'The Basilica Aemilia Frieze: Religion and Politics in Late Republican Rome'. Latomus 49, 801-815.

Alföldi, A. E. Z., 1956. 'The Main Aspects of Political Propaganda on the Coinage of the Roman Republic'. In: R. A. G. Carson, C. H. V. Sutherland (ed.), Essays in Roman Coinage Presented to Harold Mattingly. [London]: Oxford University Press, 63-95.

Bartolli, A., 1950. 'Il fregio figurato della Basilica Emilia'. Bollettino d'Arte 35, 289-294.

Beazley, J., 1963. Attic Red-Figure Vase Painters. Second edition. Oxford: Clarendon Press.

BMC I = H. Mattingly, Coins of the Roman Empire in the British Museum. Volume I. Augustus to Vitellius. London: British Museum, 1965.

Böhm, S., 1997. Die Münzen der Römischen Republik und ihre Bildquellen. Mainz: von Zabern.

Cairns, F., 2011: 'Tarpeia Pudicitia in Propertius 1.16.2 - And the Early Roman Historians'. Rheinisches Museum für Philologie. N. F. 154, 176-184.

Cohen, B., 1997. 'Divesting the Female Breast of Clothes in Classical Sculpture'. In: A. O. Koloski-Ostrow, C. L. Lyons (ed.), Naked Truths. Women, Sexuality and Gender in Classical Art and Archaeology. London / New York: Routledge, 66-92.

Evans, J. D., 1992. The Art of Persuasion. Political Propaganda from Aeneas to Brutus. Ann Arbor: The University of Michigan Press.

Furuhagen, H., 1961. 'Some Remarks on the Sculpted Frieze of the Basilica Aemilia in Rome'. Opuscula Romana 3, 142-144.

Gansiniec, Z., 1949. Tarpeia, the Making of a Myth [= Acta Societatis Archaeologicae Polonorum I]. Wratislaviae: Societas Archaeologica Polonorum.

Helbig, W., 1886. 'Minos und Skylla: ein pompejanisches Wandgemälde'. Archäologische Zeitung 24, 195-199.

Holliday, P. J., 1997. 'Roman Triumphal Painting: Its Function, Development and Reception'. The Art Bulletin 79, 130-147.

Küter, A., 2014. Zwischen Republik und Kaiserzeit. Die Münzmeisterprägung unter Augustus. Berlin: Gebr. Mann Verlag.

Laufer, E., 1985. Kaineus. Studien zur Ikonographie [= Rivista di archeologia. Suppl. 1]. Rome: Giorgio Bretschneider Editore.

LIMC = J. Boardman et al., Lexicon Iconographicum Mythologiae Classicae. Zurich / Munich / Düsseldorf: Artemis \& Winkler Verlag, 1981-2009.

Reinach, S., 1908. 'Tarpeia'. Revue archéologique. Quatrième série 11, 43-74.

RIC I = C. H. V. Sutherland, The Roman Imperial Coinage. Volume I. From 31 BC to AD 69. Revised ed. London: Spink and Son Ltd., 1984.

Richardson, L., 1992. A New Topographical Dictionary of Ancient Rome. Baltimore: John Hopkins University Press.

Richter, G. M. A., 1971. The Engraved Gems of the Greeks, Etruscans and Romans. Part II. Engraved Gems of the Romans. A Supplement to the History of Roman Art. London: Phaidon Press.

Ridgway, B. S., 2000. Hellenistic Sculpture II. The Styles of ca. 200-100 BC. Madison: University of Wisconsin Press.

$\mathrm{RRC}=$ M. H. Crawford, Roman Republican Coinage. London: Cambridge University Press, 1974.

Smith, A. H., Murray, A. S., 1888. A Catalogue of Engraved Gems in the British Museum (Department of Greek and Roman Antiquities). London: Printed by order of the Trustees.

Weinstock, S., 1955. 'Zofia Gansiniec, Tarpeia, the Making of a Myth'. The Journal of Roman Studies 45, 239-240.

Welch, T. S., 2015. Tarpeia. Workings of a Roman Myth. Columbus: Ohio State University Press. 


\title{
LIST OF FIGURES
}

Fig. 1. The Punishment of Tarpeia. Basilica Aemilia frieze. Museo Nazionale Romano. Source: https:// en.wikipedia.org/wiki/File:Frieze_Basilica_Aemilia_Massimo_n3.jpg. The figure of the soldier in the right corner of the scene is missing on this photograph.

Fig. 2. The Punishment of Tarpeia. AR denarius, L. Titurius Sabinus, 89 BC. RRC 344/2. Source: https:// en.wikipedia.org/wiki/Tarpeia\#/media/File:Tarpeia_coins.jpg

Fig. 3. The Punishtment of Tarpeia. AR denarius, Augustus, issued by P. Petronius Turpilianus, 19 BC. RIC I Augustus 299. Source: https://en.wikipedia.org/wiki/Tarpeia\#/media/File:Augustus_Denarius 2300268.jpg

Fig. 4. Etruscan alabaster cinerary chest with the relief showing the Punishment of Dirce, from Volterra. 120-110 BC. Staatliche Museums Berlin, no. 1278. Source: https://commons.wikimedia.org/wiki /File:Altes_Museum_-_Vorderseite_einer_Aschenkiste,_Schleifung_der_Dirke.jpg

Fig. 5. The gem with the Death of Dolon. Museum of Fine Arts, Boston (MFA 27.740). Drawing: A. Waldhauserová.

Fig. 6. The Death of Caeneus. Etruscan black figure stamnos. Kunsthistorisches Museum Wien no. 406 IV 1477.

\section{POTRESTÁNÍ TARPEIE A JEHO MOŽNÉ IKONOGRAFICKÉ VZORY}

Téma potrestání Tarpeie, tolik oblíbené antickými autory, se v římském výtvarném umění objevuje překvapivě zřídka. Dochované památky nicméně vykazují značnou podobnost, která svědčí o shodném zdroji vizuální inspirace. Článek se zaměřuje na hledání ikonografických paralel potrestání Tarpeie v řeckém a etruském výtvarném umění, vedle srovnání se způsobem zobrazení ryze záporných postav typu Dirké a Dolóna se věnuje i nápadným podobnostem mezi potrestáním Tarpeie a některými výjevy ubití Kainea. Zatímco v tomto př́padě zřejmě ovlivnily podobu nového ikonografického schématu jen podobné okolnosti skonu obou protagonistů, v případě Dirké a Dolóna se patrně jedná o hlubší inspiraci založenou na obsahové př́buznosti témat či dílčích motivů.

\author{
Lenka Vacinová \\ National Museum, Prague; Charles University, Prague \\ lenka.vacinova@centrum.cz
}

